\title{
Quality of Pre-school Learning Environment in Palestine
}

\author{
Reem Jawabreh", ${ }^{1, *}$ İpek Danju ${ }^{1}$, Soheil Salha ${ }^{2}$ \\ ${ }^{1}$ Faculty of Education Sciences, Curriculum \& Instruction, Near East University, Turkey \\ ${ }^{2}$ Faculty of Education Sciences, Curriculum \& Instruction, An-Najah National University, Palestine
}

Received July 2, 2020; Revised August 6, 2020; Accepted September 11, 2020

\section{Cite This Paper in the following Citation Styles}

(a):[1] ReemJawabreh, IpekDanju, SoheilSalha, "Quality of Pre-school Learning Environment in Palestine," Universal Journal of Educational Research, Vol. 8, No. 10, pp. 4769 - 4775, 2020. DOI: 10.13189/ujer.2020.081048

(b):ReemJawabreh, IpekDanju, SoheilSalha (2020).Quality of Pre-school Learning Environment in Palestine. Universal Journal of Educational Research, 8(10), 4769 - 4775. DOI: 10.13189/ujer.2020.081048.

Copyright $@ 2020$ by authors, all rights reserved. Authors agree that this article remains permanently open access under the terms of the Creative Commons Attribution License 4.0 International License

\begin{abstract}
The current study aimed at assessing the quality of pre-school learning environment in Palestine. Learning quality is considered as a significant indicator of human sustainability. Pre-school learning is part of a basic education strategy to enrich and support children's development during the critical, formative years from birth to five years. The sample of this study was stratified random with (180) preschool teachers from the district of Nablus. The researchers adopted the quantitative methodology by using the ECERS-R questionnaire to assess the quality of pre-school learning environment. Statistical analysis detected that the quality of pre-schools learning environment according to the ECERS-R scale had high levels on the domains of language, activities, interaction, program structure and parents and staff. Furnishing and personal care routine had moderate levels of quality. It can be inferred relative weaknesses in the learning environment in Palestinian pre-schools with certain items yielding weakly level. Thus, it can be concluded that all the items can still be improved. The last result showing that there was a significant difference in the quality of preschool learning environment according to teachers' educational qualification, generally, the current study recommended the significance of continuing to supply effective quality learning environments in pre-schools in Palestine.
\end{abstract}

Keywords Quality, Learning Environment, Preschool, Palestine

\section{Introduction}

Good environments supplying new learning opportunities throughout early childhood are really essential for the development and creation of the children, and thus the most purpose of the pre-school learning is to help children succeed, and have psychological, emotional and social development.

Teaching pre-school children is extremely hard task because teachers need to be able to respond to their curiosity, understand their age requirements, and provide proper learning environment by facilitating their methods of learning. The quality of pre-school care and education has acquired appreciable attention and became a priority for academic practitioners and policymakers. Actually, the quality of learning environment needs development in numerous regions all over the world (Anning, Joy \& Marilyn, 2004; Kalkan\&Akman, 2009). Analysis over the previous thirty years has demonstrated that the educational setting was being a sturdy determinant of the children's learning.

Pre-school learning environments ought to motivate and inculcate the needs as well as developmental stages of children (Rossiter, 2016).

Studies proved that education throughout the first years featured a very long time lasting impacts on the formation of children, and researchers particularly confirmed the significance of education throughout this era, so early childhood years is significant within the formation of a child's intelligence, temperament, and social behaviors (Whitebread, 2015). 
"The Palestinian kid is our hope, and infancy education is the technique and basic component in order to achieve our future as a country. So, let us invest in the Palestinian kids and bolster them to rise." This was told by the minister of education and higher education in Palestine 'Sabri Saidam' in May 2016.

In the past two years, several countries had a priority to supply early health care, especially for the poorest and most marginalized kids, and raised awareness of early childhood development and took imperative action to ensure all children have procuration to health, education, play, and the development of the pre-school education structure would be an important contribution to efforts to raise enrolment and holding of children in preschools, as well as getting better the quality of services provided for children (Nasser, 2018).

Learning environment is a term that has psychosocial and pedagogical characteristics, as well as physical locations, since students may learn outside of school environments, this term is used limited term of a room with desks and a chalkboard, it also involves the culture of a school, its ethos, and features, including how individuals communicate with one another, the strategies in which teachers may use for teaching (Bates, 2019).

Because of the impact of the quality of the learning environment on good learning outcomes, and based on previous studies conducted, this survey will evaluate the quality of the pre-school learning environment in Palestine.

\section{Statement of the Problem}

Pre-school is the most significant educational period, , so kids in the early childhood duration should not be alone. Effective learning environment is necessary for implementing the learning process, there are many items that form a quality learning environment. Children usually learn by using concrete elements and objects, and they build their understanding by using manipulative materials. Rich learning environments could strengthen the quality of children learning.

Related studies sought to find out quality signs in early childhood education, It has been detected that quality in early childhood education is affected by the physical environment and equipment, educational qualification for teachers, class size, teachers-children interactions, and the syllabus which is implemented (Espinosa, 2002).

In light of the above mentioned reasons, the present research is utilized to clarify the status of kindergarten learning in Palestine. Hence, the problem of this study is determined by answering the subsequent main question: What is the quality of pre-school learning environment depending on the teachers' point of view in Palestine?

\section{Purpose of the Study}

The eventual fate of the Palestinian economy is based on their children who got to be educated, especially pre-school education (UNICEF, 2011). Therefore, the quality of the pre-school learning environment is great attention-grabbers in Palestine as a result of their basic effect on children's development, thus it's necessary to conduct exhaustive report to evaluate the pre-schools learning environment in Palestine, and the aim of the current research is to investigate the quality of the pre-school learning environment in Palestine.

\section{Objectives of the Study}

This study aims to the following:

1. To assess and describe the quality of the preschool learning environment in Palestine.

2. To recognize the strengths and gaps of the pre-schools learning environment in Palestine.

3. To find out if there is a statistical significant difference in the quality of pre-school learning according to teachers' academic qualifications.

\section{The Research Questions}

The following questions related to quantitative data:

1. What is the status of the preschool learning environment from the points of view of teachers in Palestine?

2. What is the strength and gap of the preschool learning environment from the points of view of teachers in Palestine?

3. Is there any statistical significant difference in the quality of the preschool learning environment according to teachers' academic qualifications?

\section{Previous Studies}

Mihăescu and Andron (2019) stated that preschool is the starting point for formal education, and it is an important milestone that lays the foundation for everlasting learning and child development in full. Therefore, at this stage, children need a play-based approach that meets overall development, so that they will be better prepared for the urgent challenges of primary education and also to learn for life.

Raoa, Richardsa, Sunb, Weberc and Sincovichda (2019) stated that children who received early childhood education had a much better cognitive, linguistic and social development than those who did not. Early childhood education dosage has been positively associated with cognitive, social and emotional grades in China, and language grades in Mongolia. In general, the results indicated that childhood education is helpful for the development of children, and it must be intensified efforts to ensure that kids access to quality childhood education.

Alkhales and Natsheh (2019) sought to understand the practices of preschool teachers in the aspect of science education for children in surveyed. The study sample comprised 10 preschool teachers and 300 children in Jerusalem governorate in the State of Palestine. The results explained that the practice of meditation helped teachers to apply the investigative stages in science education for 
children: asking questions, research, implementation, results and creativity, and the development of children's investigative skills.

Karademir, Cingi, Dereli and Akman (2017) pointed out that quality in pre-school education is a direct fit to the appropriateness of the learning environment provided to children according to their needs, interests, characteristics, and age. In addition, providing an educational environment for kids by teachers is very significant. Therefore, pre-school learning is a good quality if provided in an environment where kids can be independent, express their feeling, and have the opportunity to improve their creative lives to become autonomous.

Manning, Garvis, Fleming, and Wong (2017) examined the relationship between the quality of the pre-school learning environment and qualifications of teachers, the results showed that there was a positive correlation between them, as the educational high level of teachers is correlated to a high-quality learning environment in early childhood. Furthermore, there is also an affirmative linkage between teacher qualification and ECERS-R questionnaire items containing: program structure and language, finding strategies that could boost the learning results in early childhood.

Syrjämäki, Sajaniemi, Suhonen, Alijoki, and Nislin (2017) aimed to explore the learning environment in early childhood and emphasized on the concept of interaction, and kid's participation boosted, the quality of learning environment was assessed by quantitative qualitative data as good, especially in activities and space.

Pianta, Downer, and Hamre (2016) intended to check the quality of the pre-school learning environment, and they used 3 appraisals to detect the quality by the ECERS-R scale. The results demonstrated that teachers with educational experiences and preparation in early childhood education helped to improve the quality of learning.

Allen and Kelly (2015) explained that the experiences experienced by children in the first three to six years of their lives affected their emotional, cognitive, physical and social development, where they began to explore the world, provide them with an environment in which children can absorb the world around them, learn to speak, and listen to others. Therefore, it is necessary to supply a powerful start by providing an experience based on sound theoretical foundations suitable for growth, to ensure the future success of the children.

ALdarab'h, Abo Alrub and Al-Mohtadi (2015) described the reality of pre-schools in the Hashemite Kingdom of Jordan. The sample consists of 500 pre-school teachers. The results indicated that the quality of government primary schools by ECERS-R scale was an excellent quality in two branches, and they are the interaction and substructure of programs, while the other branches of furnishings, language, personal care routine, activities, and parents were good quality. The research revealed the significance of continuity to equip a good status educational environment in Jordanian pre-schools and integrating their assessment into education reform.

Shaari and Ahmad (2015) indicated that there is a relation between kids preparedness to school and physical learning environment, and concluded that well-prepared physical environment will encourage the evolution and learning of kids, and will contribute to enhance pre-school preparation, thus will be an advanced educational system, by encouraging their opportunities of achievement which will be beneficial for the kids in future.

TsiakaraDigelidis (2015) tried to find out the effect of the learning environment on pre-school kids' performance, the findings demonstrated that kids who had a good learning environment, their performance as well and they felt joyful. Moreover, objectives and learning environments influence preschool children's attitudes toward their performance.

Bassok, Fitzpatrick, Loeb, and Paglayan (2013) detected that families prefer teachers with bachelor's degrees to teach their kids, as this will give their kids the best educational experiences, comparison with teachers who have a high school diploma or parallels it.

Shahein (2013) determined the extent to which the Early Childhood Resource Center training programs contribute to pre-school education in Palestine according to the level of education. The findings demonstrated that there were statistical significant differences with regard to the contribution of training programs in the Early Childhood Resource Center based on the level of education, where these differences were in favor of the teachers with a high level in education.

Zmily, Class, Mowafi, and Abu-Saymeh (2013) suggested a new strategy for an effective learning environment that focused on finding fun for children, and this effective learning environment uses portable smart devices and supplied with WLAN and NFC to boost the learning environments and provide the educational content.

Guseva, Dombrovskis, Murasovs, and Ilisko (2012) believed that a learning environment is as fundamental and important in preparation Kindergarten, pre-school learning environment confirms on the whole upbringing of kids by considering cognitive, psychomotor and emotional development of a kid as an integral part of a cultural and social environment. These studies highlighted the role of the pre-school environment toward the development of the child, and thus that the correct understanding of the learning environment, leads to adopting it is in pre-school curriculum design.

Fraser (2012) indicated that learning environment is considered as the third teacher and plays a main role in what and how child learns, and it provides for the flexible and creative use of time, space, and materials to make a response to children's interests and needs, and researchers believed that a key to learning is the social space more than the physical space including early childhood education.

Blake and Howitt (2012) detected methods and basics of teaching in the early childhood, where their study showed 
that Children's knowledge can be developed through supporting them, and through the directed interaction between them and their teachers by playing, also providing activities.

Worthington (2008) focused on the way and how to use the components of the pre-school environment to find a perfect learning environment, as well as on teaching strategies in the English language and the development of its aspects, to increase the number of children who learn English, thereby enhancing their language skill, regardless of their native language.

Abdullah (2007) aimed to evaluate the quality of the pre-school learning environment in private and public by using the ECERS-R scale. The results demonstrated that the status of public pre-school was better than the status of private pre-schools, because it was at a high level of quality, especially in activities and program structure.

Al-Taib (2006) aimed to assess the status of governmental pre-schools in Kuwait, by using the scale of (ECERS-R). The results showed thatquality learning in pre-schools was at a moderate level in some branches like program structure, furnishings, language, personal care routines, and activities.

Dudek (2000) believed that learning environment is a term given to extending beyond the physical environment of the space in which learning takes place to include psychosocial and pedagogical characteristics and the effect of places on students outside the school.

\section{Methodology}

The researchers used a quantitative approach and ECERS-R form designed to examine the quality of the pre-school environment, which consists of 7 fundamental domains: furnishing, personal care routines, language, activity, interaction, program structure, parents. The form is a 43-item rating scale divided into 7 subscales, the components in the initial six subscales are referenced to as children related, and the components in the last subscale are referenced to as parent-staff related (Harms, Clifford, \& Cryer, 1998).

\section{Study population and sample}

The population of this study included all the preschool teachers at Nablus directorate of Education. Nablus city is located on the north of Palestine. The total of preschool teachers is 422 according to Nablus directorate of Education in 2019. The sample was stratified random with (180) preschool teachers, presenting (53) kindergartens. It is worth noting that all preschool teachers are females.

\section{Results}

The researchers used SPSS.23 to analyze data from the questionnaire. After analyzing the data, Study questions were answered as follows:

1. What is the quality of the preschool learning environment from the points of view of teachers in Palestine?

The findings of the analysis indicated that the pre-school learning environment had a high level of 5 domains of the quality of the learning environment.

These 5 domains are Language $(\mathrm{M}=3.73$, S.D. $=0.39)$, Program Structure $(\mathrm{M}=3.73$, S.D $=0.57)$, Activities $(\mathrm{M}=$ 3.65, S.D. $=0.34)$, Parents and Staff $(M=3.62$, S.D $=0.41)$, and Interaction $(\mathrm{M}=3.54$, S.D. $=0.41)$. The findings additionally showed that the quality of the pre-school learning environment was at moderate level in another two domains are Furnishings $(\mathrm{M}=3.45$, S.D. $=0.34)$ and Personal Care Routine $(\mathrm{M}=3.40$, S.D. $=0.38)$.

Table 1. Level of quality of pre-school learning environment in Palestine

\begin{tabular}{|c|c|c|c|}
\hline Domain & Mean & S.D & Level \\
\hline Furnishing & 3.45 & 0.34 & Moderate \\
\hline Personal Care Routine & 3.40 & 0.38 & Moderate \\
\hline Language & 3.73 & 0.39 & High \\
\hline Activities & 3.65 & 0.34 & High \\
\hline Interaction & 3.54 & 0.41 & High \\
\hline Program Structure & 3.73 & 0.57 & High \\
\hline Parents and staff & 3.62 & 0.41 & High \\
\hline
\end{tabular}

2. What is the strength and gap of the preschool learning environment from the points of view of teachers in Palestine?

The findings of the analysis showed that the Programs Structure and Language Reasoning are at a high level $(\mathrm{M}=$ 3.73), (see Table 1). It should be noted here that these two domains elucidate the strength of the quality of the pre-school learning environment in Palestine, as both domains had a mean more than (3.5). While the findings of the analysis demonstrated that Furnishing $(M=3.45)$, Personal Care Routines $(\mathrm{M}=3.40)$, and Interaction $(\mathrm{M}=$ 3.54) are at a low level contrasted with the above-mentioned domains previously. So, it is concluded that these three subscales are the relative gaps in the quality of the learning environment in Kindergartens with other elements yield to a very low level mean. Thus, it can be concluded that all the items can still be improved.

3. Is there any significant difference in the quality of the preschool learning environment according to teachers' academic qualifications?

To answer this question, the researchers used the t-test of independent variables. Table (2) shows the findings: 
Table 2. Means, standard deviations and t-test of quality of preschool learning environment according to teachers' academic qualifications

\begin{tabular}{|c|c|c|c|c|c|c|c|}
\hline Domain & $\begin{array}{l}\text { Educational } \\
\text { qualification }\end{array}$ & $\mathrm{N}$ & Mean & S.D & d.f & $\mathrm{t}$ - value & Sig. \\
\hline \multirow{2}{*}{ Space and Furnishing } & Diploma & 118 & 3.41 & 0.33 & \multirow{14}{*}{178} & \multirow{2}{*}{1.896} & \multirow{2}{*}{0.060} \\
\hline & B.A & 62 & 3.51 & 0.35 & & & \\
\hline \multirow{2}{*}{ Personal Care Routine } & Diploma & 118 & 3.35 & 0.42 & & \multirow{2}{*}{2.691} & \multirow{2}{*}{$0.008^{*}$} \\
\hline & B.A & 62 & 3.51 & 0.28 & & & \\
\hline \multirow{2}{*}{ Language Reasoning } & Diploma & 118 & 3.68 & 0.39 & & \multirow{2}{*}{2.506} & \multirow{2}{*}{$0.013^{*}$} \\
\hline & B.A & 62 & 3.83 & 0.39 & & & \\
\hline \multirow{2}{*}{ Activities } & Diploma & 118 & 3.55 & 0.32 & & \multirow{2}{*}{5.618} & \multirow{2}{*}{$0.001^{*}$} \\
\hline & B.A & 62 & 3.83 & 0.32 & & & \\
\hline \multirow{2}{*}{ Interaction } & Diploma & 118 & 3.48 & 0.39 & & \multirow{2}{*}{3.106} & \multirow{2}{*}{$0.002^{*}$} \\
\hline & B.A & 62 & 3.67 & 0.41 & & & \\
\hline \multirow{2}{*}{ Program Structure } & Diploma & 118 & 3.76 & 0.58 & & \multirow{2}{*}{0.905} & \multirow{2}{*}{0.367} \\
\hline & B.A & 62 & 3.68 & 0.55 & & & \\
\hline \multirow{2}{*}{ Parents and Staff } & Diploma & 118 & 3.62 & 0.41 & & \multirow{2}{*}{0.119} & \multirow{2}{*}{0.905} \\
\hline & B.A & 62 & 3.63 & 0.42 & & & \\
\hline
\end{tabular}

The results in Table 2 shows that there is a significant difference in the quality of preschool learning environment according on teachers' academic qualifications in the domains of Personal Care Routine, Language, Activities, and Interaction in favor of B.A holders, while there are no significant differences in the domains of Furnishing, Program Structure, and Parents.

\section{Discussion}

Kids spend most of their time in classrooms, so it is necessary to create effective classrooms learning environment, there are many considerations which been adopted to institutionalize a quality learning environment for preschool.

This study revealed the quality of the pre-school learning environment in Palestine. This is important for the Ministry of Education to improve the early childhood learning environment and boost kids and their families, and this will contribute to achieving positive lifelong results that will promote and improve the entire community.

The results of the first question in this study showed that the pre-school learning environment had good level on 5 domains of the quality of the learning environment, which were consistent with the results of previous studies, such as Mihăescu and Andron (2019) that showed that children's need an approach that meets overall development, and preschool is the starting point for formal education, as well as the study of Raoa et al. (2019) that revealed that childhood education is helpful for the development of children, and It must be intensified efforts to ensure that kids access to quality childhood education, as well as Karademir et al. (2017) that detected that pre-school learning is a good quality if provided in an environment where kids can act independent, express their feeling, and have the opportunity to improve their creative lives to become autonomous.

A quality of pre-school learning environment is one of the foundations of kindergarten, where it needs support, improvement, and development. It should be noted that some elements showed the strength of the quality of learning environment, but it is not a sufficient indication to judge the quality of the educational environment in pre-school, where results of the second question in this study showed that there are the relative gaps of the quality of the learning environment in Kindergartens. Thus, it can be concluded that all the items can still be improved, which were consistent with the results of previous studies, such as Syrjämäki et al. (2017) which emphasized on the concept of interaction, and kid's participation boosted, where was the quality of learning environment was a good, especially in activities and space, as well as the study of ALdarab'h et al. (2015) that showed that the quality of government primary schools by ECERS-R scale was an excellent quality in interaction and substructure of programs, whilst the others branches of furnishings, language, personal care routine, activities, and parents weregood quality, and it revealed the significance of continuity to equip a good status educational environment in pre-schools and integrating their assessment into education reform. And an Al-Taib study (2006) that showed the quality learning in pre-schools was at a moderate level in some branches like program structure, furnishings, language, personal care routines, and activities.

Socio-physical relation that teachers create with kids around their environment is important for learning in early childhood, and preschool teachers should be well 
preparedto meet the needs of the children. In general, the classroom form and arrangement must be organized and attractive to provide an opportunity for children to learn and interact. Where the results of the third question in this study showed that there was a significant difference in the quality of preschool learning environment according to teachers' academic qualifications in specific domains like Personal Care Routine, Language, Activities, and Interaction in favor of B.A holders, while there were no significant differences in other domains like Furnishing, Program Structure, and Parents. The results of this study were consistent with the results of previous studies such as the study of Manning et al. (2017), which revealed that there is an affirmative linkage between teacher qualification and ECERS-R questionnaire items containing: program structure and language, and the educational high level of teachers is correlated to a high-quality learning environment in early childhood. As well as the study of Pianta et al. (2016) that demonstrated that teachers with educational experiences and preparing in early childhood education will help to improve the quality. And a Bassok study (2013) detected that families prefer teachers with bachelor's degrees for their kids, so as to give their kids the best educational experiences, comparison with teachers who have a high school diploma or parallels it.

\section{Recommendations}

This research explained the significance of continuing to provide a good quality of pre-school learning environment in Palestine. Where data analysis detected that developments in the quality of the learning environment must be based on an obvious strategy, and have to involve as follows:

(1) Training of preschool teachers', which will help to upgrade the pedagogic and communication skills of all kindergarten teachers, thus, and prepare children for the transference from preschool to the primary.

(2) Expand funding, because a completely-prepared physical environment gives young children a feeling of belonging, and enables them to share, also gives parents a sense of welcomed and involved.

(3) Assist with the provision of learning materials, teacher training as a part of longer-term capacity-building for the Ministry of Education, and such efforts must include not just teachers but parents, the government and community at large.

(4) Developplans to meet the multiple interests and needs of kids and their parents to assure their readiness for the school.

\section{Conclusions}

To conclude, we hope to provide a comprehensive learning environment of pre-school, we hope to guide the teachers and assist in planning and implementing the developmentally suitable activities for our children, and they should be in a safe, secure and stimulating environment, and all this can be done only if there is a complete agreement, cooperation, and support among all those who are relevant with the pre-schools learning.

\section{REFERENCES}

[1] Abdullah, M. H. (2007). Evaluate the public and private Kindergarten in Egypt. (Unpublished doctoral dissertation). Egypt: Aean Shams University.

[2] ALdarab'h, I., Abo Alrub, M., Al-Mohtadi, R. (2015). What is the Reality of Preschool in Jordan?.Journal of Education and Practice, 6(10).

[3] Alkalies, B., \&Natsheh, I. (2019). Science Inquiry Journey for Children through Teacher's Reflective Practices in Jerusalem (Qualitative Study). Dirasat Journal 46(4).

[4] Allen, R., \& Kelly, B. (2015). Committee on the Science of Children Birth to Age 8: Deepening and Broadening the Foundation for Success; Board on Children, Youth, and Families; Institute of Medicine; National Research Council. Washington (DC): National Academies Press (US).

[5] Al-Taib, E. J. (2006). The status of the government kindergarten in Kuwait. Studies Journal, 7 (4), 243-255.

[6] Anning, A., Joy, C., \& Marilyn, F. (2004). Early childhood education, society, and culture. London: Sage Publications.

[7] Bassok, D., Fitzpatrick, M., Loeb, S., \&Paglayan, A. S. (2013). The early childhood care and education workforce from 1990 through 2010: Changing dynamics and persistent concerns. Education, 8(4), 581-601.

[8] Bates, A.W. (2019). Teaching in a Digital Age - Second Edition. Vancouver, B.C.: Tony Bates Associates Ltd. Retrieved from https://pressbooks.bccampus.ca/teac.

[9] Blake, E., \& Howitt, C. (2012). Science in early learning centers: satisfying curiosity, guided play or lost opportunities? In K. Tan \& M. Kim (Eds.), Issues and challenges in science education research. Dordrecht: Springer.

[10] Bronson, M.B. (2000). Self-regulation in early childhood: Nature and nurture. New York, NY: The Guilford Press.

[11] Broström, S., \& Wagner, J. T. (2003). Transitions in context: Models, practicalities and problems. In S. Broström\& J. T. Wagner (Eds.), Early childhood education in five Nordic countries: Perspectives on the transition from preschool to school (pp. 27-36). Arhus: Systime Academic.

[12] Dudek, M. (2000). The architecture of schools: The new learning environments. London: Architectural Press. Evidence for Policy and Practice Information and Co-ordinating Centre EPPI-Centre. EPPI-Center methods for conducting systematic reviews. London: EPPI-Centre, Social Science Research Unit, Institute of Education, University of London. 
[13] Einarsdottir, J. (2011). Icelandic children's early education transition experiences. Early Education and Development, 22, 737-756.

[14] Espinosa, L. (2002). High-Quality Preschool: Why We Need It and What It Looks Like. Rutgers National Institute for Early Education Research.

[15] Fabian, H., \& Dunlop, A. W. (2002). Transitions in the early years: Debating continuity and progression for children in early education. London: Routledge Falmer.

[16] Fraser, S. (2012). Authentic Childhood: Experiencing Reggio Emilia in the classroom (3rd ed.). Toronto: Nelson Education.

[17] Guseva, S. A., Dombrovskis, V. B., Murasovs, V. C., Ilisko, D. D. (2012). The sustainability-designed learning environment for pre-school children: The case of Latvia (Article). International Journal of Early Childhood Learning. 19(4), 15-26.

[18] Harms, T., Clifford, R., \& Cryer, D. (1998). Early childhood environment rating scale- revised. New York: Teachers College Press.

[19] Kalkan, E. \&Akman, B. (2009). Examining preschools quality in terms of physical conditions. Social and Behavioral Sciences, 1, 1573-1577.

[20] Karademir, A., \&Cingi, M., \&Dereli. F., \&Akman, B. (2017). Quality in Preschool Education: The Views of Teachers and Assistant Teachers, Hacettepe and Kastamonu University, Turkey, 12(23), 7-33.

[21] Kaufman, R., S., \&Pianta, R. (2000). An ecological perspective on the transition to kindergarten: A theoretical framework to guide empirical research. Journal of Applied Developmental Psychology, 21, 491-511.

[22] Manning, M., Garvis, S., Fleming, C. \& Wong, G. (2017). The relationship between teacher qualification and the quality of early childhood care and learning environment. Campbell Systematic Reviews 2017:1. The Australian National University, Australia DOI: 10.4073/csr.2017.1.

[23] Mihăescu\& D. Andron (2019). Proceedings of the 19th biennial conference of international study association on teachers and teaching (ISATT) "Education beyond the crisis: new skills, children's rights, and teaching contexts", (pp.120-124). Sibiu: Lucian Blaga Publishing House. ISBN: 978-606-12-1659-8.

[24] Nasser, I. (2018). https://theirworld.org/voices/how-curricul um-framework-for-kindergarten-education-palestine-was-la unched.

[25] Pianta, R., Downer, J., \& Hamre, B. (2016). Quality in Early Education Classrooms: Definitions, Gaps, and Systems. The Future of Children, 26(2), 119-137. Retrieved from www.jstor.org/stable/43940584

[26] Rao, N., \&Richardsa, B., \&Sunb, J., Weberc, A., \&Sincovichda, A. (2019). Early childhood education and child development in four countries in East Asia and the Pacific. Faculty of Education, The University of Hong Kong,
Hong Kong. Early Childhood Research Quarterly 47, 169181.

[27] Rossiter, J. (2016). Scaling Up Access to Quality Early Education in Ethiopia: Guidance from International Experience, 8, University of Oxford (UK). Dept of International Development, ODID. Young LivesYoung Lives Policy Paper 8.

[28] Shaari, M., and Ahmad, S. (2015). Physical Learning Environment: Impact on Children School Readiness in Malaysian Preschools. Social and Behavioral Sciences 222, $9-18$.

[29] Shahein, N. (2013). Contribution of Early Childhood Resource Center Training Programs in the Professional Development for Kindergarten Principals and Teachers. Master thesis. Birzeit University, Palestine.

[30] Smiley, P. A., \& Dweck, C. S. (1994). Individual differences in achievement goals among young children. Child Development, 65, 1723-1743.

[31] Stabback, P. (2016). What Makes a Quality Curriculum? Current Critical Issues in Curriculum and Learning, 2, 8-12. Retrieved from:http://unesdoc.unesco.org/images/0024/002 439/243975E.pdf.

[32] Stipek, D., Feiler, R., Daniels, D., \& Millburn, S. (1995). Effects of different instructional approaches on young children's achievement and motivation. Child Development, 6(10),209-223.

[33] Syrjämäki, M., Sajaniemi, N., Suhonen, E., Alijoki, A., and Nislin, M. (2017). Enhancing peer interaction: an aspect of a high-quality learning environment in Finnish early childhood special education. European Journal of Special Needs Education, 32(3), 377-390.

[34] Tsiakara, A., and Digelidis, N. (2015). Learning environment and type of goals: how it affects preschool children's performance and their perceptions of their performance?,Early Child Development and Care, 185(3), 464-474.

[35] UNICEF (2011). School Readiness and Transitions. UNICEF's Division of Communication, UNICEF.

[36] Whitebread, D. (2015). Quality in Early Childhood Education: an International Review and Guide for Policy Makers. Contemporary Issues in the Early Years pp. 47-62.

[37] Wildenger, L. K. \& McIntyre, L. L. (2012). Investigating the relation between kindergarten preparation and child socio-behavioral school outcomes. Early Childhood Education Journal, 40, 169-176.

[38] Worthington, E. (2008). Effective learning environments in preschools. (master's thesis, Human Development, and Family Studies, Lowa State University).

[39] Zmily, A., Class, C., Mowafi, Y. and Abu-Saymeh, D. (2013). An Interactive Educational Environment for Preschool Children, 15th Intl. Conf. on Enterprise Information Systems, Angers, France. 